\title{
MICROSCOPY TECHNIQUES ARE EFFECTIVE TOOLS FOR IMPLEMENTING STUDIES IN DAIRY SCIENCE AND TECHNOLOGY
}

\author{
PAOLO D’INCECCO (*), LUISA PELLEGRINO (*)
}

SuNTO. - Il latte è un sistema polifasico nel quale lipidi, proteine, zuccheri e sali sono presenti in forme di aggregazione molto diverse, che ne determinano la diversa stabilità e il comportamento durante i processi di trasformazione. I lipidi sono in forma di globuli, del diametro di alcuni $\mu \mathrm{m}$, che rimangono in emulsione grazie alla presenza di una membrana fosfolipidica che li avvolge. La caseina, che rappresenta circa $80 \%$ delle proteine del latte, è presente in forma di aggregati micellari di 50-500 nm, stabilizzati da fosfato di calcio e fortemente idratati in superficie grazie alla presenza di segmenti proteici glicosilati. Globuli di grasso e micelle di caseina interagiscono tra loro molto facilmente, dato che in $1 \mathrm{~mL}$ di latte vi sono circa $10^{10}$ globuli e $10^{14}$ micelle, con una superficie esposta di 0,07 e di $4 \mathrm{~m}^{2}$ rispettivamente. Queste interazioni, più o meno numerose e stabili in funzione delle condizioni che le hanno determinate (trattamenti termici o ad alta pressione, acidificazione, azioni enzimatiche), sono alla base della trasformazione del latte in prodotti derivati con caratteristiche diverse. Le tecniche microscopiche consentono di comprenderne la natura e l'evoluzione durante la trasformazione o la conservazione, e di comprenderne la correlazione con la macrostruttura del prodotto finito. La microscopia confocale laser a fluorescenza con l'utilizzo di sonde specifiche consente di apprezzare fenomeni di coalescenza tra globuli di grasso o le relazioni grassoproteine, sia in matrici liquide (latte) che in gel (latte coagulato) o in matrici semisolide (formaggio). Con la microscopia elettronica e l'immuno-oro-marcatura è possibile caratterizzare interazioni tra specifiche proteine e la membrana dei globuli di grasso o interazioni tra quest'ultima e antigeni localizzati nelle membrane batteriche. Lo studio di matrici complesse come quelle alimentari richiede un approccio multidisciplinare nel quale la moderna microscopia svolge un ruolo indispensabile.

$* * *$

ABSTRACT. - Milk is a complex system where lipids, proteins, sugars and salts are present in different phases, and thus shows a characteristic behaviour during either technological

(*) Dipartimento di Scienze per gli Alimenti, la Nutrizione e l'Ambiente, Università degli Studi di Milano, Italia. E-mail: paolo.dincecco@unimi.it 
treatments or storage. Lipids are organized as globules, small drops of triglycerides surrounded by a biological membrane that ensures stability of their emulsion. Casein is the main milk protein and is organized as micelles containing salts and strongly hydrated. This last feature has an important effect on the micelle stability. Furthermore, micelle stability is ensured by glycosylated k-casein fragments. Interaction between fat globules and casein micelles are likely to occur since $\sim 10^{10}$ globules e $10^{14}$ micelles are present in $1 \mathrm{~mL}$ of milk and their reactive surface is approximately 0.07 and $4 \mathrm{~m}^{2}$ respectively. Different milk processes, i.e. mechanic or thermal, are responsible for interactions which may vary in number and chemical nature. Microscopy techniques represent an indispensable tool to study milk microstructure during milk processing or even on finished products upon storage. Confocal laser scanning microscopy, through specific probes, is suitable to study phenomena of coalescence among fat globules and fat-protein interactions in fluid milk, gel (clotted milk) or cheese. Transmission electron microscopy and immunogold labelling are used to more deeply investigate either milk components ultrastructure or specific interactions established between the milk fat globule membrane and the casein fractions. Food products are matrices where a multidisciplinary approach is necessary for their study, and microscopy certainly plays a key role.

\section{INTRODUCTION}

Milk is a fluid secreted by the female of all mammalian species and its primary function is meeting the nutritional requirements of the new-borns. Considering that nutritional and physiological requirements of each species are rather unique, the composition of milk shows a very high inter-species variability. The gross composition of cow milk is reported in Tab. 1. Lactose, fat and protein, which is $78 \%$ casein, represent the major milk components and thus are most frequently involved in interactions. However, the soluble whey proteins and minerals participate in a variety of structural modifications by disulphide bond formation, for instance, as well as by regulating the ionic strength of the water phase (Fox, 2009). Milk has a colloidal nature that affects its microstructure, quality as well as processing behaviour. The colloidal system can be divided in two compositional and physic domains, the casein micelle and the milk fat globule. The number of casein micelles is $10^{14} / \mathrm{mL}$ with a reactive surface of $4 \mathrm{~m}^{2} / \mathrm{mL}$. The number of fat globules is $10^{10} / \mathrm{mL}$ with a reactive surface of $0.07 \mathrm{~m}^{2} / \mathrm{mL}$. Therefore, the structure and interactions of these colloidal particles are important research areas. The different microscopy techniques (optical, confocal, electronic) are indispensable tools for the detection and investigation of structures characterized by dimensions in the order of few microns, or even less, and therefore are largely adopted in dairy research. 
Tab. 1. Gross composition ( $\mathrm{g} / 100 \mathrm{~mL}$ ) of cow's milk.

\begin{tabular}{lc}
\hline Component & Average content \\
\hline Water & 87.3 \\
\hline Fat & 3.9 \\
\hline Protein & 3.2 \\
\hline Casein & 2.6 \\
\hline Whey proteins & 0.65 \\
\hline Lactose & 4.6 \\
\hline Minerals & 0.14 \\
\hline
\end{tabular}

\section{MiLK FAT}

Fat in milk is organized into globules, ranging from 0.1 to $15 \mu \mathrm{m}$ in size (Michalski et al., 2004), and represents an emulsion of lipid droplets in a water phase. The milk fat globule is structurally and compositionally complex. Two main portions can be distinguished: the milk fat globule membrane (MFGM), an outer layer mostly made by phospholipids that allow the emulsion stability, and the triglyceride (TAG) core. The chemical composition of TAGs varies depending on seasonal dietary changes, breed and the lactation stage of the cows. The MFGM also evolves after its secretion and especially during processing. Fig. 1a, $b$ show how the MFGM and TAG core of raw milk can be specifically stained and observed by confocal laser scanning microscopy (CLSM). The TAG core was stained by the fluorochrome Nile red, (concentration of $1 \mathrm{mg} / \mathrm{mL}$ in DMSO) that is able to cross the membrane, whereas $\mathrm{N}$-(lissamine rhodamine B sulfonyl) dioleoylphosphatidyl ethanolamine (Rh-DOPE, concentration of $1 \mathrm{mg} / \mathrm{mL}$ in chloroform) was used to label the phospholipids in the MFGM. Nile red was excited at $488 \mathrm{~nm}$ using an Ar laser and the emission filter was set at 520-590 nm. The Rh-DOPE was excited with a He-Ne laser operating at $543 \mathrm{~nm}$ and emission wavelength detected between $565 \mathrm{~nm}$ and $615 \mathrm{~nm}$.

TAGs contain short (4:0-6:0), medium (8:0-12:0) and long ( $>14: 0)$ chain fatty acids; saturated fatty acids represent 65 to $70 \mathrm{wt} \%$, with 16:0 corresponding to 22 up to $35 \mathrm{wt} \%$, and low amount of unsaturated fatty acids, mainly 18:1 (Lopez, 2011). Due to the broad range of melting temperature, there is a coexistence of crystalline and liquid fat between $-40^{\circ} \mathrm{C}$, where it is completely solid, and $40^{\circ} \mathrm{C}$, where it is 
completely liquid (Hillbrick and Augustin, 2002). TAGs in the core are well organized into layers according to their melting points, and this organization can be observed in high resolution images of fat globules obtained by freeze-fracture replication of raw milk followed by transmission electron microscopy (TEM) analysis (Fig. 2).
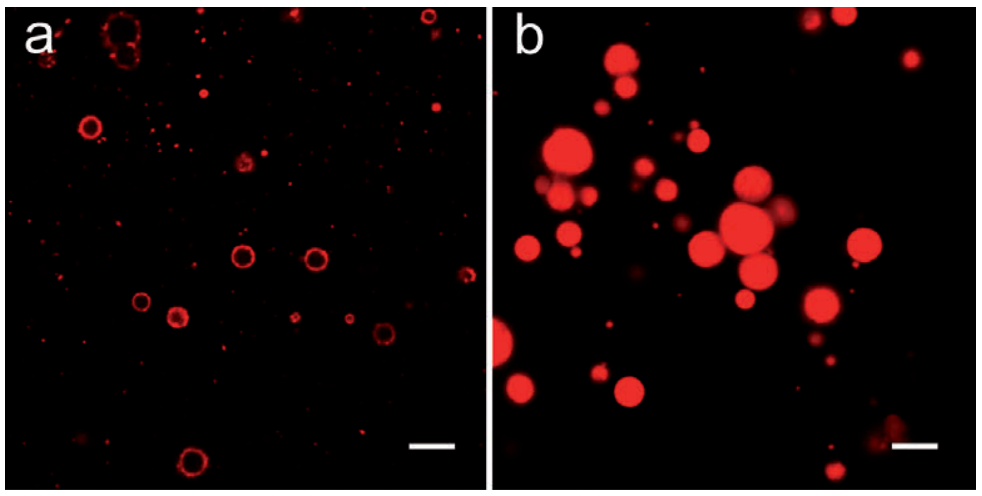

Fig. 1. Confocal laser scanning microscopy of fat globules in raw milk. The surrounding biological membrane (a) is made visible by specific labelling of phospholipids with $\mathrm{N}$-(lissamine rhodamine B sulfonyl) dioleoylphosphatidyl ethanolamine whereas the internal core (b) is observed when triglycerides are stained with Nile red. Scale bar: 5 um.

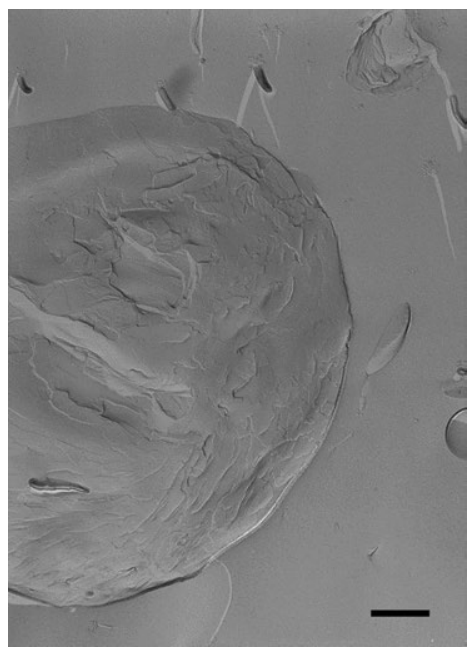

Fig. 2. Transmission electron micrograph of a freeze-fractured milk fat globule in raw milk. The globule fractured convexly. The cross-fracture shows the layers of the crystallized triglycerides revealing an onion-like inner structure of the globule. Scale bar: $450 \mathrm{~nm}$. 
The presence of the MFGM surrounding the globule limits or delays the impact of destabilization phenomena, such as flocculation, coalescence and spontaneous creaming, while protecting TAG from lipolytic enzymes (Lopez, 2011). A work by Lopez et al. (2010) showed the structure of MFGM as a triple layer of phospholipids filled with proteins, glycoproteins, enzymes, neutral glycerides, cerebrosides, cholesterol and water. The protein in the MFGM represents about $1 \%$ of the total milk protein (Fong et al., 2007). The MFGM is reported to be approximately $10 \mathrm{~nm}$ thick but variations in thickness in different zones of the same globule and from one globule to another are suggested to arise from different surface activity of milk components against MFGM (Walstra and Jennes, 1984). The irregular thickness of MFGM was observed using CLSM and staining the MFGM by the lipophilic probe DilC $_{18}$ (3)-DS (Fig. 3). The MFGM looked bright but heterogeneously stained. The absence of fluorescence in some portions could be interpreted either as the lack of a phospholipid bilayer or as the presence of co-existing fluid and gel phases that impair membrane staining (Evers et al., 2008). Recently, Lopez et al. (2011) suggested that local differences in the thickness of the MFGM could be due to the liquid ordered domains of sphingomyelin with long-chain saturated fatty acids.

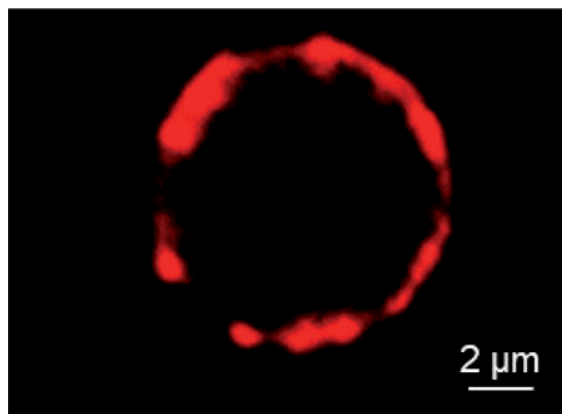

Fig. 3. Confocal laser scanning micrograph showing the emission fluorescence of the milk fat globule membrane (MFGM) stained with Dil $C_{18}(3)-D S$ fluorescent probe. Non-fluorescent zones observed in the MFGM reveal its complex composition.

\section{MILK PROTEINS}

Casein represents $78 \%$ of the milk protein and is organized in micelles having diameter ranging from 50 to $500 \mathrm{~nm}$. Four main casein 
fractions, namely $\alpha_{\mathrm{s} 2}, \alpha_{\mathrm{s} 1}, \beta$ and $\mathrm{k}$, are present in the ratio 1:4:4:1, respectively. Soluble whey proteins, mainly $\beta$-lactoglobulin and $\alpha$-lactalbumin, having monomeric structure, represent the remaining $22 \%$ of the milk protein.

Some different structural models have been proposed to explain how casein fractions aggregate into the micelle; however, no one of these has been definitely accredited. Despite this, all of the models agree on the preponderance of $\mathrm{k}$-casein on the micelle surface because of its ability to extend the glycosylated terminal polypeptide several nanometres beyond the micelle surface. This makes the surface of the micelle extremely hydrated and creates a steric repulsion among micelles which prevents their interaction unless environmental conditions change. Different electron microscopy approaches have been used to investigate the complex micelle microstructure and it has been determined that cryo-preparation minimises deformation of the micelles and preserves their original structure. Accordingly, cryoand freeze-dried TEM studies reached the same conclusion, i.e. there is no evidence of the presence of sub-micelles as distinct subunits (De Kruif and Holt, 2003; Holt, 2016; Wanige et al., 2004). However, consensus is achieved on the lack of a uniform structure, as shown by freeze-fracturing of micelles concentrated by ultrafiltration of raw milk (Fig. 4).

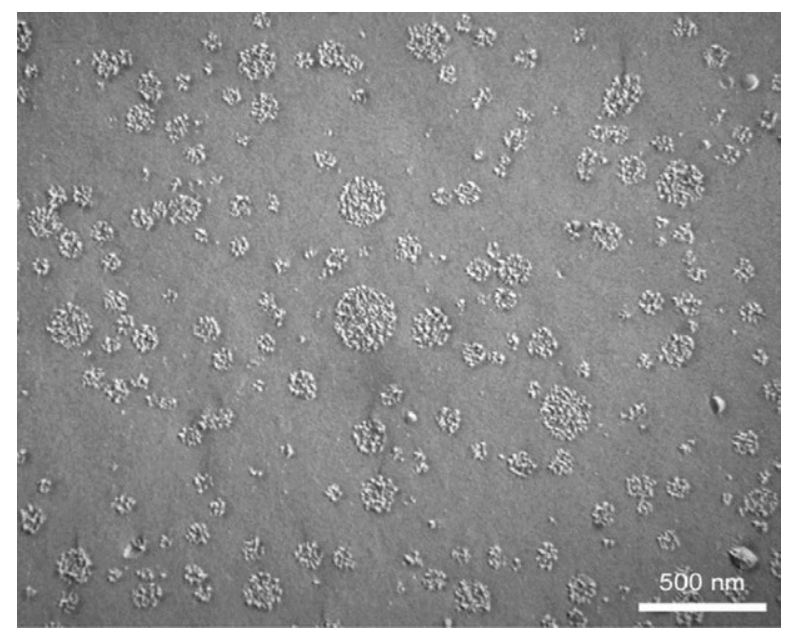

Fig. 4. Freeze-fracture transmission electron micrograph of casein micelles concentrated by ultrafiltration of raw milk. The technique gives a section through the micelles. 


\section{CASE STUDY 1: DOUBLE HOMOGENIZATION FOR EXTENDING THE SHELF STORAGE STABILITY OF UHT MILK}

Milk is normally homogenized and heat treated (pasteurized or sterilized) to obtain a stable, microbiologically safe food. Homogenization itself increases the milk fat globule surface by reducing the fat globule size (Lopez, 2005). When milk is subjected to homogenization, casein micelles as well as whey proteins often stick on the surface of disrupted fat globules to repair the broken areas of MFGM. The increased density of the globules makes the time for their rise longer and delays the formation of a cream layer on top of the milk. Ultra-high temperature (UHT) sterilized milk commonly has a commercial shelf life of 3-4 months. However, emerging markets require for this product to be stable up to 12 months, thus new technological strategies have to be applied to reach this goal. In a recent study, we evaluated if the stability of fat in UHT milk could be increased by changing the conventional homogenization process. The effect of a double homogenization (experimental) with respect to a single process (conventional) was studied on UHT milk upon storage in sealed packages. Changes in fat globule size distribution were studied by means of laser light scattering, and the ultrastructure of fat globules was evaluated by CLSM and TEM (D'Incecco et al., 2018). In particular, the second homogenization step was carried out after the thermal treatment, and adopting a pressure higher than the conventional process. After 12 months of storage at room temperature, a thick layer of cream was present on top in the packages of conventionally homogenized milk. Differently, experimental samples were still physically stable since no fat creaming took place. Light scattering analysis was performed on milk samples, as long as they did not destabilize during the storage period (Fig. 5). The averages $\mathrm{D}_{4.3}$ and $\mathrm{D}_{3.2}$ of fat globules were smaller in the homogenized samples than in the control milk. The average $\mathrm{D}_{4.3}$ of the fat globules decreased from $0.44 \pm 0.03$ in the conventional sample to $0.34 \pm 0.00$ in the experimental sample. Likewise, the $\mathrm{D}_{3.2}$ decreased from $0.31 \pm 0.05$ to $0.28 \pm 0.00$. In fact, the volume of fat represented by globules with a diameter ranging $0.16-0.63 \mu \mathrm{m}$ was smaller in the conventional sample than in the experimental sample, and the volume of globules in the range $0.63-1.90 \mu \mathrm{m}$ was larger. The shoulder observed in the distribution curve of the conventional sample, and corresponding to globules $\sim 2-4 \mu \mathrm{m}$ in diameter, lacked in the experimental sam- 


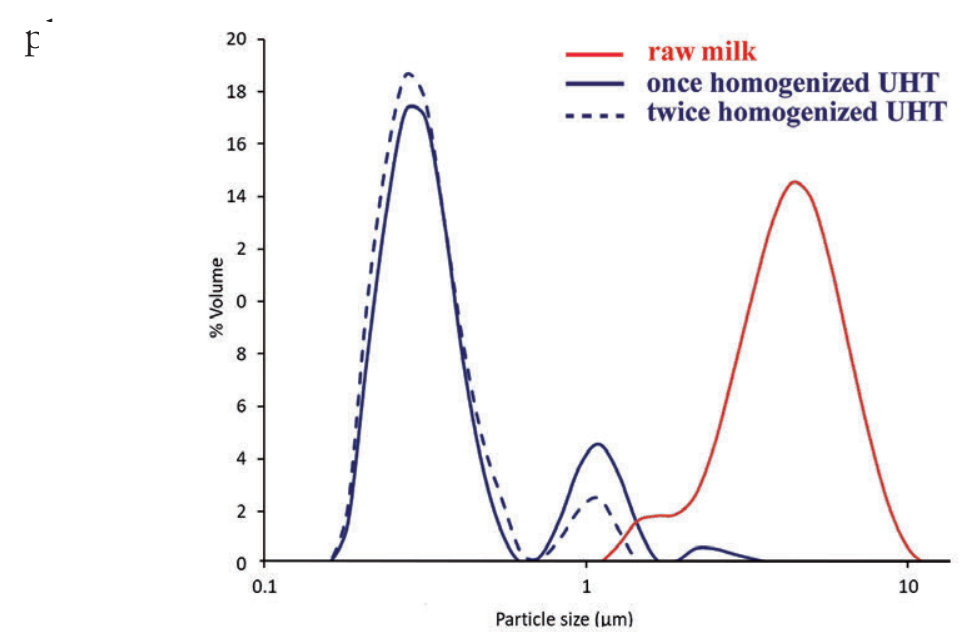

Fig. 5. Light scattering (LS) analysis of raw milk (solid red line) and UHT milk homogenized either once (solid blue line) or twice (dashed blue line). All samples were sonicated for 5 sec and kept mixing at $1000 \mathrm{rpm}, 40^{\circ} \mathrm{C}$ during LS measurement. At least three measurements were carried out for each milk sample.

CLSM showed larger fat globules in the conventional samples (Fig. 6), consistently with the results obtained by light scattering analysis. The second homogenization increased the number of fat globules significantly $(\mathrm{P}<0.05)$. Fat globules counted by image analysis were 2200 in the experimental sample and 1100 in the conventional one. The difference in fat globule size deriving from the two homogenization processes determined a longer storage stability in the double-homogenized sample.

The ultrastructure of fat globules and casein micelles in the two milk samples was further investigated by TEM, and raw milk was used as a reference for the native situation. Free casein micelles were the predominant species in raw milk (not shown); instead, micelles shared among clusters of fat globules were observed in the conventional sample. Differently, broken clusters and presence of free fragments of MFGM were observed in the experimental sample, possibly due to the second homogenization step positioned downstream to the thermal treatment (Fig. 7).

Overall, our results showed that repeating the homogenization treatment could effectively delay fat creaming in UHT milk up to 12 months. The microscopy study was strategic for interpreting the effect of the double homogenization and revealed the significant improvement in milk stability we observed. 


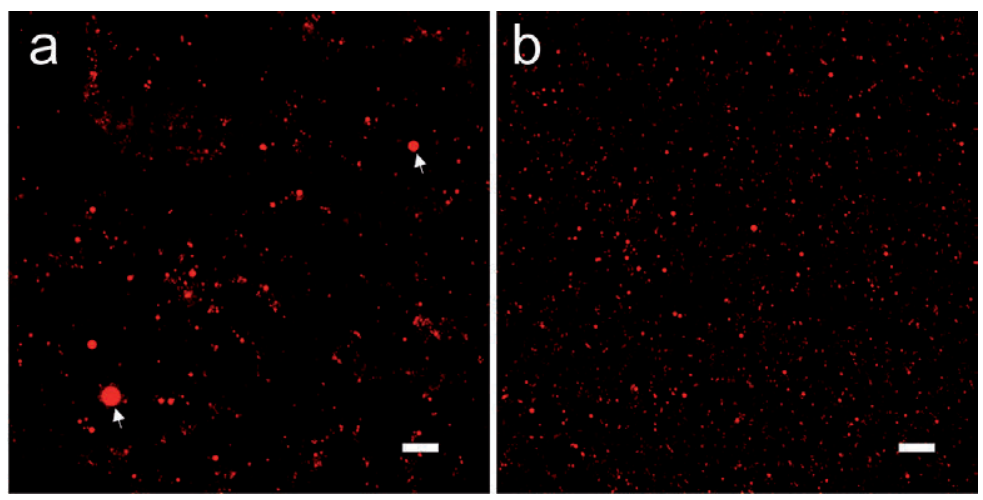

Fig. 6. Confocal laser scanning microscopy images showing the microstructure of the fat globules in once (a) or twice (b) homogenized UHT milk. Large fat globules (arrows) are visible only in the conventionally treated sample. The Nile red stained fat globules appear red. Scale bars: 5 um.
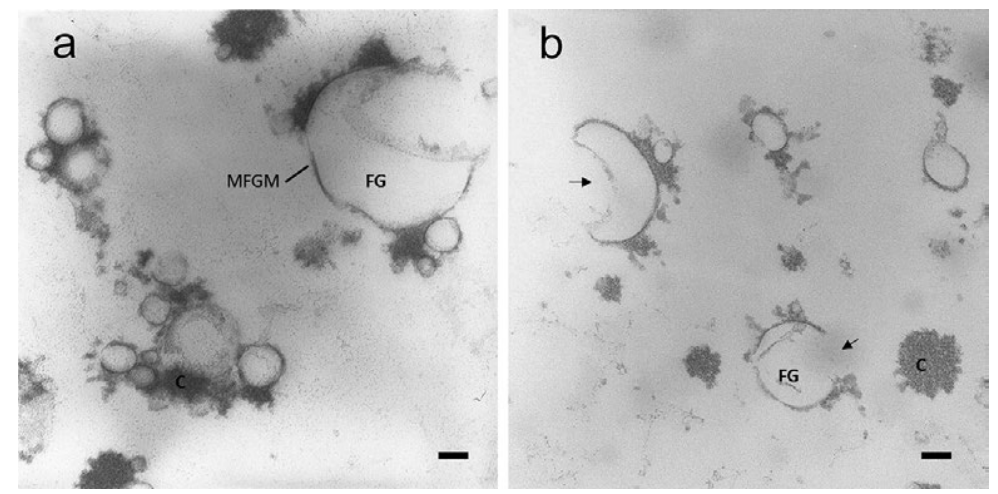

Fig. 7. TEM micrographs of fat globules (FG) in once (a) or twice (b) bomogenized UHT milk. Numerous small casein micelles $(C)$ are stuck to the milk fat globule membrane (MFGM) as a consequence of the technological treatments. Numerous damaged fat globules (black arrows) are present in double bomogenized sample. Scale bars: $100 \mathrm{~nm}$.

CASE STUDY 2: EFFECT OF TEMPERATURE ON THE SUPRAMOLECULAR ORGANIZATION OF FAT GLOBULES DURING NATURAL CREAMING OF MILK

Natural creaming occurs when fat globules rise to the surface in unagitated raw milk (Ma and Barbano, 2000). This process, representing the first step in manufacturing both Grana Padano and Parmigiano 
Reggiano PDO cheeses, is intended not only to partly skim the milk but also to remove somatic cells and spore-forming bacteria together with the cream (Geer and Barbano, 2014; D'Incecco et al., 2015). The spores remaining in the vat milk, especially those of Clostridium tyrobutyricum, can germinate in cheese during ripening causing the so called late blowing defect (LBD) that results in important economic losses (D'Incecco et al., 2015). Natural creaming is usually carried out at a temperature chosen by the cheesemaker on an empirical basis within a broad range of values, from $8^{\circ} \mathrm{C}$ to $20^{\circ} \mathrm{C}$, mostly based on observation and depending on the season. The creaming temperature affects the tendency of fat globules to adopt a specific supramolecular organization, i.e. to cluster or to coalesce. Clustering is thought to occur when two or more fat globules are in close contact for a substantial period of time, enabling the formation of stable aggregates. In contrast, coalescence involves the fusion of the membranes of two or more globules to form one larger unit, also arising as a consequence of contact between fat globules (Fredrick et al., 2010).

In this study, we evaluated the effect of the milk temperature during natural creaming on the supramolecular organization of fat globules. Four samples of $250 \mathrm{~mL}$ of raw milk were kept in graduated cylinders at $4^{\circ} \mathrm{C}, 8^{\circ} \mathrm{C}, 22^{\circ} \mathrm{C}$ or $40^{\circ} \mathrm{C}$. An additional sample was preheated at $37^{\circ} \mathrm{C}$ for $5 \mathrm{~min}$ in a thermostatic bath prior to creaming at $8^{\circ} \mathrm{C}$. This last trial was performed to simulate the so-called "cold milk reactivation" that is preliminarily conducted by some cheesemakers to improve the creaming attitude of their milk. The volume of cream that rose to the surface was visually evaluated at $0.5,1,3,6,8$ and $24 \mathrm{~h}$, and the fat content of the samples creamed for $24 \mathrm{~h}$ was analysed using the Babcock method. The cream samples obtained at the different temperatures were stained with Nile red and their microstructures evaluated by CLSM.

Creaming rate was faster at higher temperatures, as expected (Walstra et al., 2006). The sample pre-heated at $37^{\circ} \mathrm{C}$ showed a cream layer already after $30 \mathrm{~min}$ of incubation. Creaming temperature also influenced the cream volume: higher temperatures caused a reduction in the volume of the cream layer, probably because a surface of free oil deriving from the melted TAGs led to a greater exclusion of the aqueous phase. CLSM revealed interesting details of the supramolecular organization of fat globules obtained from the analysis of three-dimensional images (Fig. 8). 


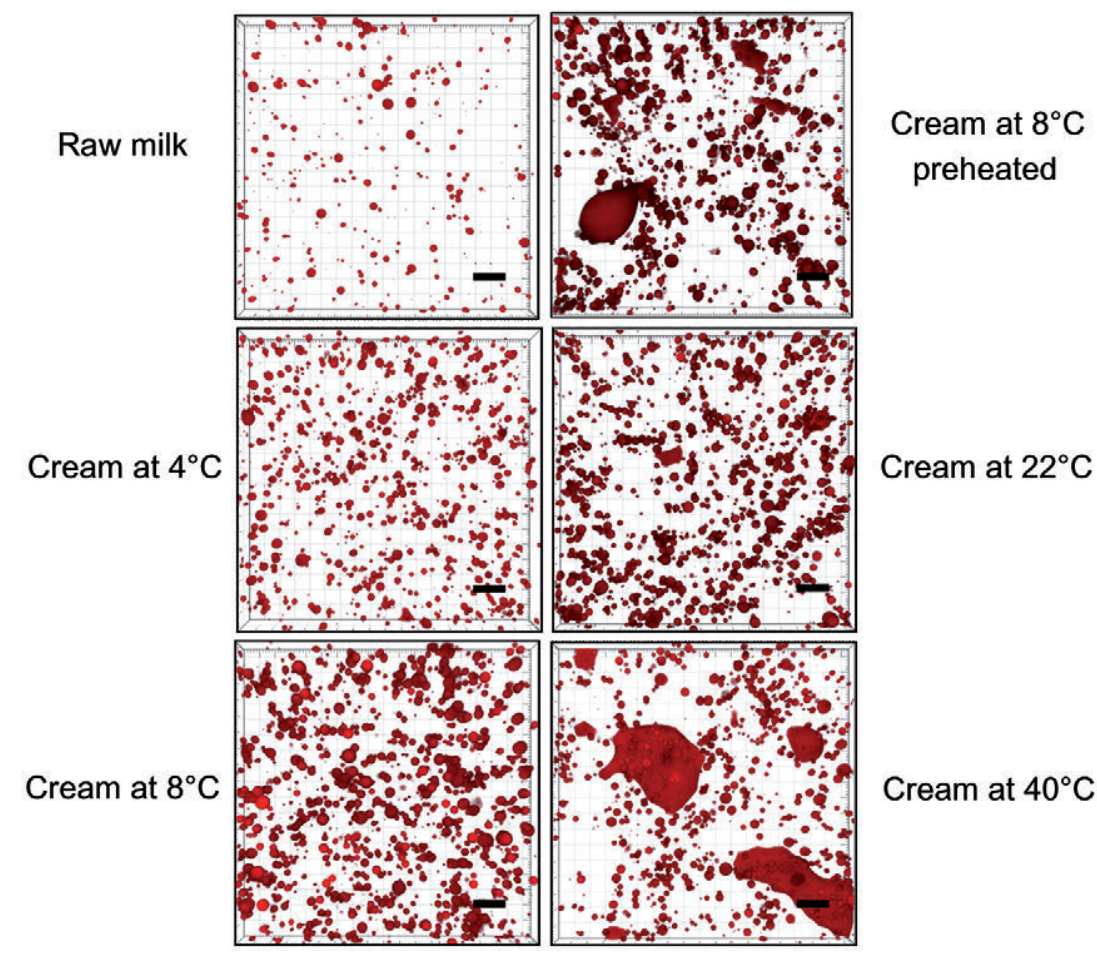

Fig. 8. Confocal laser scanning microscopy images showing the microstructure of fat in either raw milk or the derived creams collected after natural creaming at different temperatures. The Nile red-stained fat globules appear red. Scale bar: $20 \mu \mathrm{m}$.

Single fat globules were mostly present in cream obtained at either $4^{\circ} \mathrm{C}$ or $8^{\circ} \mathrm{C}$. Pre-treatment of the milk at $37^{\circ} \mathrm{C}$ prior to creaming altered the supramolecular organization of fat; distinct single fat globules decreased in number, and the extent of fat coalescence increased. Higher creaming temperatures increased fat coalescence and this was more evident at $40^{\circ} \mathrm{C}$, where large clumps of intact globules appeared entrapped in the free oil. Changes in the fat supramolecular organization were more extensive in the samples pre-heated at $37^{\circ} \mathrm{C}$ for $5 \mathrm{~min}$ before creaming at $8^{\circ} \mathrm{C}$ than in the samples creamed at $22^{\circ} \mathrm{C}$ with no pre-heating. This means that such thermal treatment, often performed by cheesemakers, can damage the milk fat globules, although it should be noted that cheesemakers typically apply heat in a continuous process whereas batch heating was applied here. 
The size distribution of fat globules, as a percentage volume, was obtained by analysing $\sim 1000$ fat globules per sample (Fig. 9). The native fat globule population present in raw milk decreased as the creaming temperature increased, and fat globules of increasing size were observed. A new population of coalesced fat globules with an average size of $\sim 28 \mu \mathrm{m}$ was observed in either samples pre-heated at $37^{\circ} \mathrm{C}$ and creamed at $8^{\circ} \mathrm{C}$ or samples creamed at $40^{\circ} \mathrm{C}$; this population represented $20 \%$ and $39 \%$ of the total fat volume in these two samples, respectively. A further small population ( $10 \%$ by fat volume) of fat globules, $\sim 17 \mu \mathrm{m}$ in size, was observed in samples creamed at $40^{\circ} \mathrm{C}$. Overall, this study showed that both the creaming at high temperatures and the milk tempering prior to natural creaming at low temperatures can compromise the integrity of the native fat globule structure. These changes, in turn, could have an effect on Grana Padano cheese making, by compromising the indispensable debacterization consequent to fat globule aggregation or MFGM-bacteria interaction. Furthermore, fat globules having a different organization behave differently in cheese coagulation and may cause modifications of the cheese structure (Everett and Auty, 2008). All these aspects are effectively investigated by combining chemical data with structure and ultrastructure evaluation.

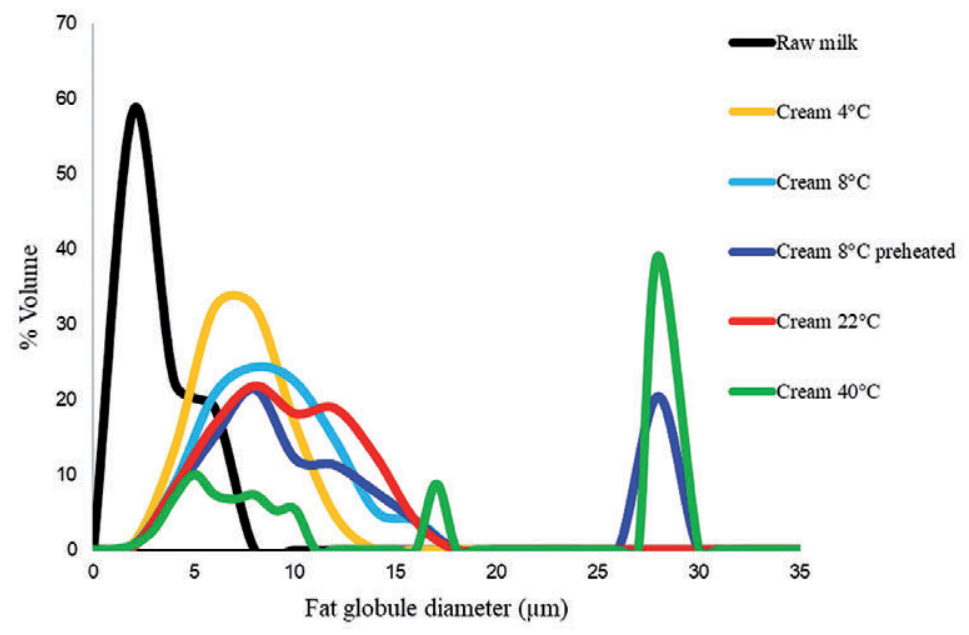

Fig. 9. Volume distribution of fat globules obtained from image analysis of the threedimensional confocal laser scanning microscopy images in Fig. 8. Cream samples were obtained from raw milk by natural creaming at different temperatures. 


\section{CASE STUDY 3: PROTEIN-FAT GLOBULE INTERACTION DURING MILK HEATING AND STORAGE}

Whereas no stable interactions among milk components are present in fresh raw milk (Sharma and Dalgleish, 1994), subsequent thermal treatments can induce a broad array of irreversible interactions, whose nature and extent are strictly dependent on the heating severity. Three general categories of heat treatment are currently recognized, although an internationally-accepted comprehensive definition is not available for all of them: thermization, pasteurization and sterilization. Thermization is a thermal process intended to decrease the level of bacterial contamination in order to improve the keeping quality rather than to eliminate pathogens; it involves heating of milk at $57-68^{\circ} \mathrm{C}$ for $15 \mathrm{sec}$. Pasteurization is a heat treatment sufficient to reduce the numbers of bacterial pathogens in milk to levels that do not constitute a risk to human health; minimum conditions are $72^{\circ} \mathrm{C}$ for $15 \mathrm{sec}$. Sterilization of milk, achieved by heating the product at 115 to $140^{\circ} \mathrm{C}$ for $2-4 \mathrm{sec}$, eliminates all pathogenic microorganisms and most vegetative spoilage organism with only a few spore-forming bacteria remaining.

As mentioned above, drinking milk is usually homogenized; thus, milk thermal treatments have their effect on an already processed matrix. In homogenized milk, casein micelles bind to the MFGM, either as intact micelles or as fragments, to cover the surface of the smaller, neo-formed fat globules. Previous studies showed that, at temperatures above $70^{\circ} \mathrm{C}$, whey proteins begin to denature. Progressively, the denatured molecules react with casein, via intermolecular disulphide bridges, and associate to fat globules. However, a number of these studies have shown that $\beta$-lactoglobulin starts interacting with the MFGM at $60-65^{\circ} \mathrm{C}$, which is below its denaturation temperature (Corredig and Dalgleish, 1991). While denaturing, whey proteins may participate in a number of possible interactions: i) interaction of $\beta$-lactoglobulin with other molecules; ii) interaction with $\mathrm{k}$-casein at the surface of casein micelles in suspension; iii) interaction with $\mathrm{k}$-casein of the casein micellar materials adsorbed on MFGM; iv) interaction with the residual membrane materials; v) direct adsorption on the MFGM, displacing adsorbed caseins. Hence, many possible interactions may occur at the same time in thermally treated milk and it may be difficult, if not impossible, to distinguish between them. Previous analyses showed that the amount of protein associated to the MFGM increases to a steady 
level as heating is prolonged (Singh et al., 2002). By using specific immunolabeling and TEM, this newly bound protein on the MFGM in UHT milk has been shown to be mostly $\beta$-lactoglobulin and k-casein (Hillbrick et al., 1999). In the same study, the specific labelling for $\beta$-lactoglobulin and k-casein appeared as doublets, triplets and multiples, suggesting that these two proteins may form complexes with themselves and each other. Differently, when pasteurization follows the homogenization, the casein micelles cover the newly formed droplets of fat and no whey proteins are present on the membrane.

Prolonged storage of dairy products at ambient or higher temperature also affects their nutritional quality, mostly with respect to the protein fraction. In fact, further protein modifications take place, also involving lactose (e.g., the Maillard reaction), as demonstrated by the progressive accumulation of some protein-bound molecular markers of heat load, such as furosine and lysinoalanine, in UHT milk or upon storage (Cattaneo et al., 2008). These reactions entail the formation of numerous covalent crosslinks between protein molecules but only few of these are known.

The effect of storage on the interaction between MFGM and proteins was evaluated, at the structural level, in UHT milk on storage. UHT milks, just after processing or at the end of four-month storage were treated by adding EDTA and $8 \mathrm{M}$ urea in the attempt to evaluate the type of interaction (Fig. 10). In fact, these solvents break down the non-covalent bonds between proteins, thus also complexes adsorbed on the fat globule surface. Samples were analysed by CLSM with or without treatment with the solubilizing solution (not shown). Results showed very few protein aggregates, often unbound to the fat globules, in UHT milk with no storage. Fat globules looked different with respect to the sample before the addition of EDTA and urea (not shown). In particular, they lost circularity and looked as coalesced fat globules. Fully different microstructure was observed in four-month stored UHT milk, where large insoluble aggregates were found. These aggregates looked like a thick protein network where fat was entrapped in. Even when smaller, protein aggregates were always bound to a fat globule cluster or just to a single globule. A possible explanation for the different microstructures observed has to consider both the effect of the added solvents and the nature of the bonds between protein and fat. In fact, considering that casein micelles partly cover the surface of the fat globules in homogenized milk, the treatment with urea and EDTA should break down these 
structures, manly stabilized by hydrophobic and ionic interactions, and this could explain the presence of small residual aggregates and coalesced fat globules in freshly produced UHT milk. Differently, since the amount of heat-induced covalent crosslinks increases during storage, as already observed by Cattaneo et al. (2008), this could explain the ability of the protein aggregates to resist the solubilisation, as we observed in four-month stored UHT milk.
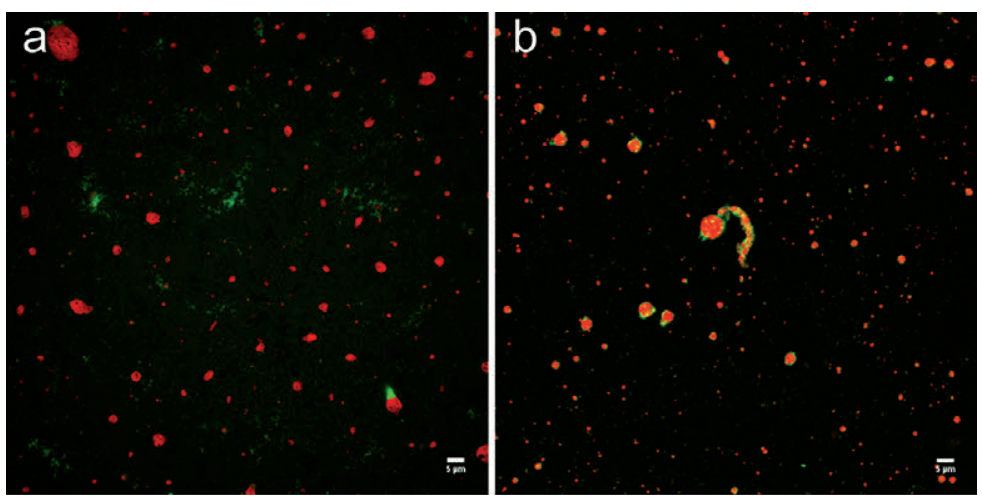

Fig. 10. Confocal laser scanning microscopy images of UHT milk, just after processing (a) or after a four-month storage (b). Milk samples were preliminarily treated by adding EDTA and $8 \mathrm{M}$ urea to disrupt hydrophobic-interactions mediated aggregates. Fat globules (red) were stained with Nile red and protein (green) by Fast Green.

\section{REFERENCES}

Cattaneo S, Masotti F, Pellegrino L. Effects of over processing on heat damage of UHT milk. Eur Food Res Technol 2008; 226: 1099-106.

Corredig M, Dalgleish DG. Effect of different heat treatments on the strong binding interactions between whey proteins and milk, fat globules in whole milk. J Dairy Res 1996; 63:441-9.

De Kruif CG, Holt C. Casein micelle structure, functions and interactions. In Advanced Dairy Chemistry - 1 Proteins. Boston: Springer 2003.

D'Incecco P, Faoro F, Silvetti T, Schrader K, Pellegrino L. Mechanisms of Clostridium tyrobutyricum removal through natural creaming of milk: A microscopy study. J Dairy Sci 2015; 98: 5164-72.

D'Incecco P, Rosi V, Cabassi G, Hogenboom JA, Pellegrino L. Microfiltration and ultrahigh-pressure homogenization for extending the shelf-storage stability of UHT milk. Food Res Int 2018; 107: 477-485.

Everett DW, Auty MA. Cheese structure and current methods of analysis. Int Dairy J 2008; 18:759-73. 
Evers JM, Haverkamp RG, Holroyd SE, Jameson DD, Mackenzie S, McCarthy OJ. Heterogeneity of milk fat globule membrane structure and composition as observed using fluorescence microscopy techniques. Int Dairy J 2008; 18:1081-9.

Fong BY, Norris CS, MacGibbon AK. Protein and lipid composition of bovine milk-fatglobule membrane. Int Dairy J 2007; 17: 275-88.

Fox PF. Milk: an overview. In: Milk Proteins. Academic Press: New York 2009: pp 1-54.

Fredrick E, Walstra P, Dewettinck K. Factors governing partial coalescence in oil-inwater emulsions. Adv Colloid Interface Sci 2010;153: 30-42.

Geer SR, Barbano DM. The effect of immunoglobulins and somatic cells on the gravity separation of fat, bacteria, and spores in pasteurized whole milk. J Dairy Sci 2014; 97: 2027-38.

Hillbrick G, Augustin MA. Milk fat characteristics and functionality: opportunities for improvement. Aust J Dairy Technol 2002; 57:45.

Hillbrick GC, McMahon DJ, McManus WR. Microstructure of indirectly and directly beated ultra-high-temperature (UHT) processed milk examined using transmission electron microscopy and immunogold labelling. Food Sci Technol 1999; 32: 486-94.

Holt C. Casein and casein micelle structures, functions and diversity in 20 species. Int Dairy J 2016; 60:2-13.

Lopez C. Focus on the supramolecular structure of milk fat in dairy products. Reprod Nutr Dev 2005; 45: 497-511.

Lopez C. Milk fat globules enveloped by their biological membrane: unique colloidal assemblies with a specific composition and structure. Curr Opin Colloid Interface Sci 2011; 16: 391-404.

Lopez C, Madec MN, Jimenez-Flores R. Lipid rafts in the bovine milk, fat globule membrane revealed by the lateral segregation of phospholipids and heterogeneous distribution of glycoproteins. Food Chem 2010; 120: 22-33.

Ma Y, Barbano DM. Gravity Separation of Raw Bovine Milk: Fat Globule Size Distribution and Fat Content of Milk Fractions1. J Dairy Sci 2000; 83: 1719-27.

Michalski MC, Ollivon M, Briard V, Leconte N, Lopez C. Native fat globules of different sizes selected from raw milk: thermal and structural behaviour. Chem Phys Lipids 2004; 132: 247-61.

Sharma SK, Dalgleish DG. Effect of heat treatments on the incorporation of milk serum proteins into the fat globule membrane of homogenized milk. J Dairy Res 1994; 61: 375-84.

Walstra P, Jenness R. Dairy Chemistry and Physics. John Wiley and Sons: New York 1984.

Walstra P, Wouters JT, Geurts TJ. Dairy science and technology. Food science and technology (Second edition). Marcel Dekker: New York 2006.

Waninge R, Kalda E, Paulsson M, Nylander T, Bergenståhl B. Cryo-TEM of isolated milk fat globule membrane structures in cream. Phys Chem Chem Phys 2004; 6: 1518-23.

Ye A, Singh H, Taylor MW, Anema S. Characterization of protein components of natural and heat-treated milk fat globule membranes. Int Dairy J 2002; 12: 393-402. 